\title{
Growth, differentiation and death of Vibrio shiloi in coral tissue as a function of seawater temperature
}

\author{
Tomer Israely, Ehud Banin, Eugene Rosenberg* \\ Department of Molecular Microbiology \& Biotechnology, Tel Aviv University, Ramat Aviv 69978, Israel
}

\begin{abstract}
The coral pathogen Vibrio shiloi was present during the summer in the tissues of all of its host corals, Oculina patagonica, which were bleached. During the winter, when seawater temperatures dropped below $20^{\circ} \mathrm{C}, \mathrm{V}$. shiloi could not be detected in either healthy or bleached corals, even when the corals were placed in aquaria and the temperature was slowly increased to $28^{\circ} \mathrm{C}$. Using specific anti- $V$. shiloi antibodies to enumerate the bacterium, it was shown that 99 to $99.99 \%$ of $V$. shiloi inside coral tissues were in a viable-but-not-culturable (VBNC) state. All attempts to culture VBNC $V$. shiloi in liquid or on solid media were unsuccessful. However, it was demonstrated that VBNC $V$. shiloi was infectious, i.e., it adhered to, penetrated into and multiplied inside corals. Laboratory aquaria experiments indicated that when corals were infected with $V$. shiloi at $28^{\circ} \mathrm{C}$ and then shifted slowly to their winter in situ temperature $\left(16^{\circ} \mathrm{C}\right)$, the bacteria died and lysed. Since the bacteria remain viable under the same temperature shifts outside the coral, either in growth media or seawater, it follows that the coral must have a host-defense mechanism for killing intracellular bacteria. The rapid killing of intracellular $V$. shiloi at $16^{\circ} \mathrm{C}$ and their absence from corals during the winter suggest that bleaching of $O$. patagonica in the Mediterranean Sea requires a fresh infection each spring, rather than the activation of dormant intracellular bacteria. The lessons learned from the V. shiloi/ $O$. patagonica model systems are discussed in terms of the general problem of the coral bleaching disease.
\end{abstract}

KEY WORDS: Vibrio · Coral bleaching $\cdot$ Temperature and infection $\cdot$ Temperature and coral bleaching

\section{INTRODUCTION}

During the last 2 decades, coral bleaching events of unprecedented frequency and global extent have been reported (Hoegh-Guldberg 1999). Coral bleaching is the disruption of symbioses between coral animals and their photosynthetic microalgal endosymbionts, the zooxanthellae (Iglesias-Prieto et al. 1992). As a result of the loss of the algae and/or their pigments, the coral turns white. The sudden loss of zooxanthellae greatly affects the coral host because these photosynthetic pigments supply up to $63 \%$ of the corals' nutrients (Glynn 1991a). The energy source derived from the algae facilitates calcification. Coral bleaching is a widespread disease that occurs in the world's 3 major oceans and in-

*Corresponding author. E-mail: eueqene@ccsg.tau.ac.il volves over 50 countries (Wilkinson 1998). It has been suggested that coral bleaching is triggered by environmental factors that impose stress on the coral. The most frequently reported stress condition is increased seawater temperature (Jokiel \& Coles 1990, Glynn 1991b, Brown 1997, Kushmaro et al. 1998). Thus, it is possible that global warming could result in alterations to or destruction of coral reef systems, the consequences of which could be devastating - to tourist and fishing industries, islands that are protected by coral reefs and, most importantly, to the health of the sea. Consequently, it is essential to understand the mechanism(s) of coral bleaching.

Bleaching of the coral Oculina patagonica from the Mediterranean Sea is the result of a bacterial infection (Kushmaro et al. 1996, 1997). The causative agent, Vibrio shiloi (Rosenberg et al. 1998, Kushmaro et al. 2001), was obtained in pure culture and shown to cause 
bleaching in controlled aquarium experiments. Furthermore, it was shown that bacterial-induced bleaching by $V$. shiloi could be inhibited by antibiotics. The infection and resulting coral bleaching was temperature-dependent, occurring only at seawater temperatures above $25^{\circ} \mathrm{C}$ (Kushmaro et al. 1998).

Using the Vibrio shiloi/Oculina patagonica model system to study coral bleaching, it was demonstrated that the first step in the infectious process was the adhesion of $V$. shiloi to a $\beta$-galactoside-containing receptor on the coral surface (Toren et al. 1998). The temperature of bacterial growth was critical for the adhesion of $V$. shiloi to the coral. When the bacteria were grown at the winter seawater temperature $\left(16^{\circ} \mathrm{C}\right)$, there was no adhesion to the coral, regardless of what temperature the coral had been maintained. However, bacteria grown at summer seawater temperatures $(25$ to $30^{\circ} \mathrm{C}$ ) adhered avidly to corals maintained at either low or high temperatures. The important ecological aspect of these findings was that the environmental stress condition, i.e., high temperature, was causing the coral bleaching pathogen to become virulent. In an attempt to understand how $V$. shiloi causes the destruction or loss of the algae, it was discovered that $V$. shiloi produces a heat-stable extracellular toxin that inhibits photosynthesis of zooxanthellae and heat-sensitive toxins that bleach and lyse the algae isolated from corals (Rosenberg et al. 1998, Ben-Haim et al. 1999, Banin et al. 2001).

Recently it was reported that Vibrio shiloi penetrates into epithelial cells shortly after adhering to the coral surface (Banin et al. 2000). The intracellular V. shiloi were observed by electron microscopy and fluorescence microscopy using specific anti- $V$. shiloi antibodies to stain the bacteria. Once inside their host, $V$. shiloi multiplied intracellularly, reaching over $10^{8}$ cells cm$^{-3}$ of coral tissue. Furthermore, intracellular $V$. shiloi were transformed into a viable-but-not-culturable (VBNC) state, which has been defined as 'a cell that can be demonstrated to be metabolically active, while being incapable of undergoing the sustained cellular division required for growth in or on a medium normally supporting growth of that cell' (Oliver 1993). In this study, we measured the numbers of intracellular $V$. shiloi in corals taken from the sea at different times of the year, the occurrence of the VBNC state in bleached corals, the infectivity of $V$. shiloi in the VBNC state and the effect of temperature shifts on the viability of $V$. shiloi in seawater, growth media and in coral tissues.

\section{MATERIALS AND METHODS}

Microorganism and growth media. Vibrio shiloi, a new species of Vibrio (Kushmaro et al. 2001), was iso- lated from a bleached coral as described previously (Kushmaro et al. 1996). The strain was maintained on MB agar (1.8\% marine broth plus $0.9 \% \mathrm{NaCl}$ solidified with $1.8 \%$ agar, both products of Difco Lab). After being streaked onto $\mathrm{MB}$ agar, the cultures were incubated at $30^{\circ} \mathrm{C}$ for $2 \mathrm{~d}$ and then allowed to stand at room temperature for $1 \mathrm{wk}$. TCBS agar (Difco MA2216), a selective medium for Vibrio, was used periodically to confirm the purity of the strain. MBTG medium is MB medium supplemented with $0.5 \%$ Tryptone and $0.1 \%$ glycerol.

Collection and maintenance of Oculina patagonica. Colony fragments of $O$. patagonica $\left(\mathrm{ca} 1 \mathrm{~cm}^{3}\right.$ ) were collected at different times during 1999-2000 from depths of 0.5 to $1.5 \mathrm{~m}$ at 2 sites along the Mediterranean Sea coastline (Bat-Yam and Jaffo). The extent of bleaching was estimated visually and the seawater temperature at the time of collection was recorded. Within $1 \mathrm{~h}$ of collection, the coral fragments were placed in aerated aquaria containing filtered seawater at the seawater ambient temperature. The aquaria were illuminated with a fluorescent lamp at $12 \mathrm{~h}$ light:12 $\mathrm{h}$ dark intervals. Coral pieces were allowed to recover and regenerate for $15 \mathrm{~d}$ before the start of each experiment (unless indicated differently). If any piece failed to heal (complete cover of damaged skeleton by new tissue), it was discarded and not used in any experiment.

Enumeration of Vibrio shiloi. The number of $V$. shiloi inside coral tissues was determined by a modification of the gentamicin invasion assay (Isberg \& Falkow 1985). The antibiotic gentamicin kills only bacteria outside the coral because it does not penetrate into coral tissues (Banin et al. 2000).

Corals were rinsed in sterile seawater and then transferred to a $50 \mathrm{ml}$ tube with $5 \mathrm{ml}$ of sterile seawater containing $0.01 \%$ of methyl- $\beta$-galactopyranoside and $200 \mu \mathrm{g} \mathrm{ml}^{-1}$ of gentamicin (both products of Sigma, St. Louis, MO, USA) in order to desorb and kill non-internalized bacteria, respectively. After incubation for $3 \mathrm{~h}$ at $29^{\circ} \mathrm{C}$, the coral was removed, rinsed in sterile seawater, then crushed in $5 \mathrm{ml}$ of sterile seawater using a mortar and pestle, and finally vortexed in a $50 \mathrm{ml}$ tube for $1 \mathrm{~min}$. Samples were taken after 2 min from the upper part of the liquid, after allowing the heavy materials to settle to the bottom of the tube. Two methods were used in order to quantitate the internal Vibrio shiloi. The first method (colony forming units, cfu) involved estimating the number of internal bacteria by plating triplicate samples of appropriate dilutions in sterile seawater on MB agar and TCBS agar. V. shiloi has a characteristic colony morphology on TCBS agar. Confirmation that the colonies were $V$. shiloi was obtained by checking the cells with specific anti- $V$. shiloi antibodies. The standard errors for all determinations of cfu were less than $10 \%$. 
The second method (total count) involved determining the number of Vibrio shiloi cells in the coral tissue microscopically after staining with specific polyclonal anti- $V$. shiloi antiserum. The crushed coral samples $(0.5 \mathrm{ml})$ were fixed at room temperature, with freshly prepared $4 \%$ paraformaldehyde in $0.45 \mathrm{M} \mathrm{NaCl}$ for 1 to $3 \mathrm{~h}$. The fixed samples were then washed 3 times in TBS (10 mM Tris- $\mathrm{HCl}, \mathrm{pH} 7.5$, in $150 \mathrm{mM} \mathrm{NaCl})$, and after $24 \mathrm{~h}$ at $4^{\circ} \mathrm{C}$ the cells were attached to microscope multitest slides (ICN, Mesa, CA, USA) covered with poly-L-lysine $\left(50 \mathrm{\mu g} \mathrm{ml}^{-1}\right)$. After incubation for $1 \mathrm{~h}$, the liquid was removed and the slides were dried for $5 \mathrm{~min}$ in $60^{\circ} \mathrm{C}$. Polyclonal antibodies raised against $V$. shiloi (Banin et al. 2000) were added to the fixed cells (30 $\mathrm{\mu l}$ of 1:500 dilution in TBS) for $12 \mathrm{~h}$ at $4^{\circ} \mathrm{C}$. (The antibodies were affinity purified by using fixed Escherichia coli and Vibrio mediterranei cells.) The slides were then washed 3 times in TBS and incubated in the dark with $5 \mu \mathrm{g} \mathrm{ml}^{-1}$ of Amca-conjugated anti-rabbit immunoglobulin G (IgG) (Jackson Immuno Research, West Grove, PA, USA). After the incubation, the slides were washed 3 times in TBS and mounted with a solution of $90 \%$ glycerol containing $1 \mathrm{mg} \mathrm{ml}^{-1}$ of $p$-phenylenediamine. Cover slips were used to seal the walls containing the fixed, stained and mounted bacteria. The sample was stored at $-20^{\circ} \mathrm{C}$ until examination. Examination was carried out using a Leica fluorescence microscope (model DMR) with filter A (UV). For each determination, at least 3 separate fields were counted. The viability of intracellular $V$. shiloi was examined with a Live/Dead BacLight Bacterial Viability Kit (Molecular Probes, Eugene, OR, USA). The bacteria were stained according to the manufacturer's protocol and then examined by fluorescence microscopy with a Leica $\mathrm{B} / \mathrm{G} / \mathrm{R}$ filter. Live bacteria fluoresce green and dead bacteria fluoresce red.

Electron microscopy. For electron microscopy, $0.5 \mathrm{ml}$ samples of exponentially growing Vibrio shiloi in MB medium and crushed coral fragments were fixed in $2.5 \%$ glutaraldehyde in filtered (pore size, $0.2 \mu \mathrm{m}$ ) seawater. After staining with $2 \%$ uranyl acetate, the bacteria were viewed with a JEOL 1200 EX electron microscope.

Laboratory infection experiments. An overnight culture of Vibrio shiloi, grown at $30^{\circ} \mathrm{C}$ in MB broth with aeration, was centrifuged at $5000 \times g$ for $10 \mathrm{~min}$, and the cell pellet was washed twice and then resuspended in sterile seawater to ca $10^{9}$ cells ml-1 . The bacteria were then inoculated into aerated aquaria containing colonies of Oculina patagonica in 21 filtered seawater $(0.45 \mu \mathrm{m})$ at $28^{\circ} \mathrm{C}$. The aquaria were illuminated with a fluorescent lamp under a $12 \mathrm{~h}$ light:12 h dark artificial lighting regime at an intensity of approximately $90 \mu$ Einst $\mathrm{m}^{-2} \mathrm{~s}^{-1}$. After standing for $3 \mathrm{~d}$ at $28^{\circ} \mathrm{C}$ to allow for the adhesion of the bacteria onto the coral, penetra- tion into the coral tissues and intracellular multiplication (Banin et al. 2000), the corals were either maintained at $28^{\circ} \mathrm{C}$ or transferred to different aquaria at varying temperatures. For each set of experiments, no bacterial inoculum controls were performed under the same conditions. At timed intervals, duplicate or triplicate corals were removed from the aquaria for determination of internal $V$. shiloi by fluorescence microscopy using anti- $V$. shiloi antibodies (total count) and $\mathrm{cfu}$, as described above.

\section{RESULTS}

\section{Seasonal variation in bleaching and internal Vibrio shiloi}

The percentage of coral colonies that showed distinct bleaching areas reached over $80 \%$ each summer from 1996 to 2000 when water temperatures exceeded $28^{\circ} \mathrm{C}$ (Fig. 1). During the winter (minimum temperature of $16^{\circ} \mathrm{C}$ ) most of the bleached colonies recovered. The number of bleached colonies increased each spring when the water temperature exceeded $20^{\circ} \mathrm{C}$ and reached a peak in August/September, approximately a month after the maximum water temperature.

Since Vibrio shiloi is the causative agent of bleaching Oculina patagonica, it was of interest to examine the concentration of $V$. shiloi inside the bleached coral tissue monthly (Table 1). From December through March less than $10^{5}$ (limit of detection) bacteria were found per $\mathrm{cm}^{3}$ coral fragment. Starting in April, the number of internal $V$. shiloi increased, reaching a maximum of $8.4 \times 10^{8} \mathrm{~cm}^{-3}$ in June. The numbers then

Table 1. Seasonal variation (1999 to 2000) of total counts of Vibrio shiloi inside bleached Oculina patagonica. The number of $V$. shiloi in $1 \mathrm{~cm}^{3}$ coral fragments taken directly from the sea were determined by fluorescence microscopy using specific anti- $V$. shiloi antibodies after removing external bacteria as described in 'Materials and methods'

\begin{tabular}{|lccc|}
\hline Month & $\begin{array}{c}\text { Temperature } \\
\left({ }^{\circ} \mathrm{C}\right)\end{array}$ & $\begin{array}{c}\text { Corals } \\
\text { examined }\end{array}$ & $\begin{array}{c}\text { Total internal } \\
\text { V. shiloi } \times 10^{6}\end{array}$ \\
\hline Jan & 18 & 2 & $<0.1$ \\
Feb & 16 & 1 & $<0.1$ \\
Mar & 16 & 3 & $<0.1$ \\
Apr & 19 & 4 & 15.0 \\
May & 22 & 3 & 26.5 \\
Jun & 26 & 4 & 843 \\
Jul & 28 & 4 & 124 \\
Aug & 30 & 4 & 35 \\
Sep & 28 & 2 & 4.1 \\
Oct & 27 & 3 & 0.1 \\
Nov & 24 & 4 & 1.8 \\
Dec & 20 & 2 & $<0.1$ \\
\hline
\end{tabular}


decreased through the remainder of the summer and fall. Thus, the maximum concentration of bacteria in the coral tissue preceded the maximum percent bleaching by 1 to 2 mo.

In addition to the bleached corals, healthy corals were also examined monthly for the present of internal Vibrio shiloi. During the summer, from June through November, none of the 15 coral fragments examined showed any internal $V$. shiloi $\left(>10^{5} \mathrm{~cm}^{-3}\right)$. This is consistent with the fact that $V$. shiloi is the causative agent of bleaching; if $V$. shiloi were present in these corals during this period of warm water, then one would expect them to bleach. From December through February, none of the 7 healthy corals examined showed

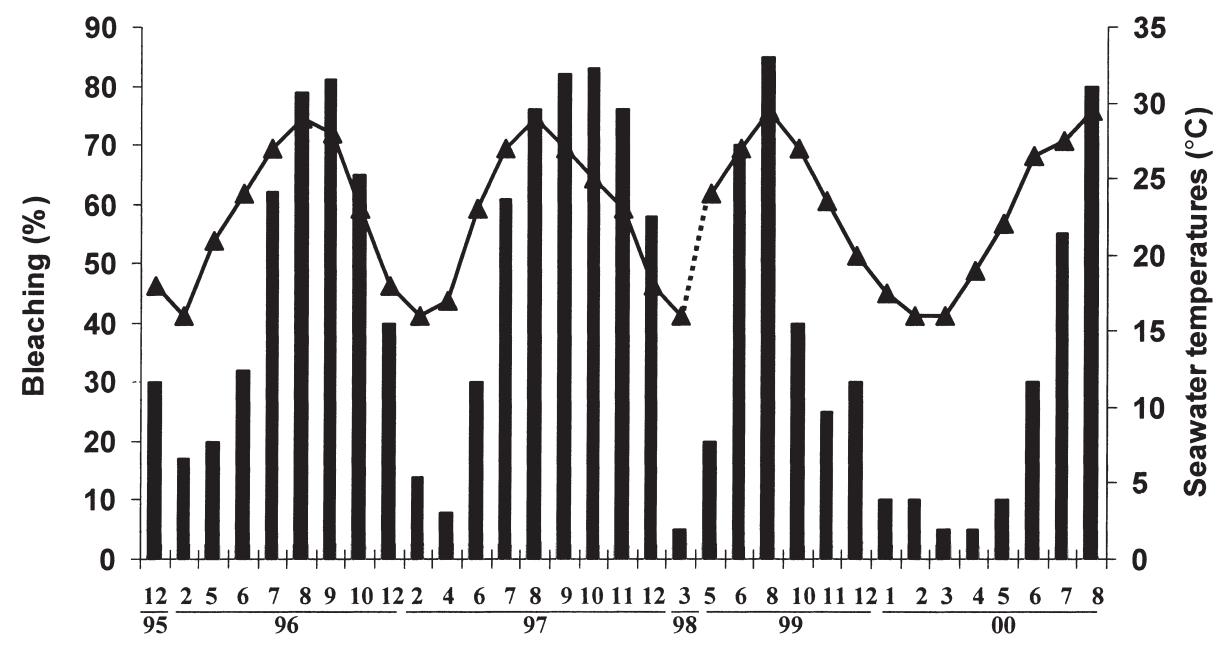

Month and Year

Fig. 1. Bleaching of Oculina patagonica in the Mediterranean Sea from 1995 to 2000 in relation to seawater temperature. Seasonal variations in seawater temperature $(\boldsymbol{\Delta})$ and percent of bleached coral colonies (bars) are plotted

$V$. shiloi. Thus, no $V$. shiloi could be found inside 7 healthy or 5 bleached corals in the winter. The only time that $V$. shiloi was found in healthy (unbleached) corals was in the spring. From March through May, 4 of the 10 corals examined showed significant numbers $\left(0.2\right.$ to $\left.1.8 \times 10^{6} \mathrm{~cm}^{-3}\right)$ of $V$. shiloi. Presumably, these corals had been infected recently and would eventually bleach.

\section{Temperature-shift experiments}

In order to better understand how water temperature affects survival of Vibrio shiloi inside coral tissues, laboratory temperature-shift experiments were performed. After infecting the corals at $28^{\circ} \mathrm{C}$ and allowing sufficient time $(3 \mathrm{~d})$ for the bacteria to adhere to the corals and penetrate into the tissue, half of the corals were transferred to a second aquarium, where the temperature was decreased $2^{\circ} \mathrm{C} \mathrm{d}^{-1}$ (Fig. 2). In the corals that were maintained at $28^{\circ} \mathrm{C}$, the bacteria multiplied reaching almost $10^{10} \mathrm{~cm}^{-3}$ and then slowly decreased to ca $5 \times 10^{8} \mathrm{~cm}^{-3}$. This concentration was maintained for $25 \mathrm{~d}$ at which time the experiment was discontinued. In the infected corals that were shifted to lower temperatures, there was a $67 \%$ decrease in bacteria $2 \mathrm{~d}$ after the temperature shifted down $\left(24^{\circ} \mathrm{C}\right)$ and an $83 \%$ decrease after $3 \mathrm{~d}\left(22^{\circ} \mathrm{C}\right)$. After $13 \mathrm{~d}\left(5 \mathrm{~d}\right.$ at $\left.16^{\circ} \mathrm{C}\right)$, no detectable $\left(>10^{5}\right)$ bacteria were observed.

Since the limit of detection for internal Vibrio shiloi was $10^{5} \mathrm{~cm}^{-3}$, temperature shift-up experiments were performed on corals taken from the sea in the winter. The rationale for this experiment was that even if a few viable $V$. shiloi were present in the coral, then by slowly raising the temperature, they would multiply and become detectable. The temperature of 10 coral fragments, taken from the sea from December to March, was slowly increased from their in situ temperature $\left(16\right.$ to $\left.20^{\circ} \mathrm{C}\right)$ to $28^{\circ} \mathrm{C}$. After being maintained at $28^{\circ} \mathrm{C}$ for 2 to $3 \mathrm{wk}$, the corals were crushed and examined for total counts and cfu. No bacteria were observed in any of the 10 coral fragments by either method.

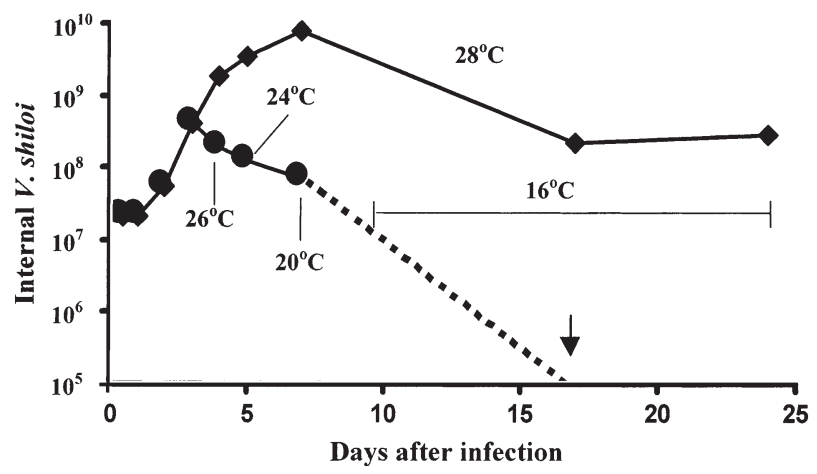

Fig. 2. Effect of temperature shift-down on Vibrio shiloi inside coral tissue. Healthy pieces of coral were infected with $V$. shiloi at $28^{\circ} \mathrm{C}$. After $72 \mathrm{~h}$, half of the corals were transferred to a second aquarium at $28^{\circ} \mathrm{C}$, and then each day the temperature was lowered $2^{\circ} \mathrm{C}$, until the temperature reached $16^{\circ} \mathrm{C}$. At timed intervals, 2 corals were taken from each aquarium for the determination of total $V$. shiloi by fluorescence microscopy 
Temperature shift-up experiments were also performed on laboratory-infected corals that had been previously shifted to $16^{\circ} \mathrm{C}$, as described in Fig. 2. Four coral fragments were infected at $28^{\circ} \mathrm{C}$, slowly adjusted to $16^{\circ} \mathrm{C}$, maintained at $16^{\circ} \mathrm{C}$ for $1 \mathrm{wk}$ and then slowly brought back to $28^{\circ} \mathrm{C}$. After 1 wk at $28^{\circ} \mathrm{C}$, the corals were crushed and examined for internal Vibrio shiloi. No bacteria were detected by total counts or $\mathrm{cfu}$, further indicating that at the winter temperature the bacteria are completely killed inside the coral tissue.

The death of Vibrio shiloi in coral tissue when shifted to temperatures below $25^{\circ} \mathrm{C}$ is due to the intracellular coral environment and not the temperature shift alone (Table 2). Bacteria grown for $3 \mathrm{~d}$ at $28^{\circ} \mathrm{C}$ and then suspended in seawater or rich culture medium showed only a small decrease in cfu when the temperature was lowered. When the bacteria were inside the coral tissue, no bacteria could be detected by the antibody method for total counts after the same temperature shift-down. Although colony counts for $V$. shiloi inside coral tissue are not reliable, because of the transition into the VBNC form (see next section), no $V$. shiloi could be detected after the intracellular bacteria were at $16^{\circ} \mathrm{C}$ for $1 \mathrm{wk}$.

\section{The VBNC state of intracellular Vibrio shiloi}

Previously, we demonstrated that Vibrio shiloi enters the VBNC state shortly after infecting corals in laboratory aquarium experiments (Banin et al. 2000). To test if in situ bleached corals also contained V. shiloi in the VBNC state, coral fragments taken from the sea were crushed and examined for total counts and plate counts. The data are presented as the ratios of total counts per colony forming unit (Table 3 ). This ratio was 1 to 3 for the control bacteria grown in MBTG medium and suspended in either seawater or rich medium. All 28 bleached corals taken from the sea showed a much higher value for total counts than plate counts, indicating the presence of the VBNC state in naturally infected corals. All of the intracellular bacteria that stained with the antibodies also scored as viable by the Live/Dead BacLight Viability Kit. In corals taken in the spring and fall, an average of 0.014 and $0.63 \%$, respectively, of the observed $V$. shiloi gave rise to colonies on standard agar plates. In corals examined in the summer, at the height of the bleaching, only $0.00013 \%$ of the $V$. shiloi were platable. An even smaller percentage of the bacteria gave rise to colonies in controlled laboratory infection experiments, 4 to $7 \mathrm{~d}$ after inoculation. It appears that during the most active part of the infection cycle, when bacteria are multiplying intracel- lularly and reaching high cell densities, they exist almost exclusively in the VBNC state.

Intracellular Vibrio shiloi has a distinctly different morphology than the same bacterium grown in culture medium (Fig. 3). Exponentially growing $V$. shiloi is a Gram-negative, motile, rod-shaped bacterium $(2.4 \times$ $1.6 \mu \mathrm{m})$ that has a single polar sheathed flagellum. When growing intracellularly in coral tissue, the bacteria lack the flagellum and are smaller $(2.0 \times 1.0 \mu \mathrm{m})$.

\section{Vibrio shiloi in the VBNC state is infectious}

From both theoretical and practical considerations it is important to know whether or not Vibrio shiloi in the

Table 3. The viable-but-not-culturable (VBNC) state of Vibrio shiloi in corals. The total and the cfu of $V$. shiloi were determined in laboratory-infected corals and bleached corals taken directly from the sea. As a control, $V$. shiloi was grown in MBTG medium for $3 \mathrm{~d}$, the cell harvested and resuspended in either sterile seawater of MBTG medium. The results are presented as the ratio of total count per cfu. n: number of corals examined

\begin{tabular}{|lcc|}
\hline \multirow{2}{*}{ Samples examined (n) } & \multicolumn{3}{c|}{ Vibrio shiloi (total count/cfu) } \\
& Average & Range \\
\hline Bleached corals from the sea & & \\
$\quad$ April, May (7) & $7 \times 10^{2}$ & $3-9 \times 10^{2}$ \\
$\quad$ June-August (12) & $8 \times 10^{4}$ & $3-13 \times 10^{4}$ \\
$\quad$ September-November (9) & $1.6 \times 10^{2}$ & $0.4-3 \times 10^{2}$ \\
Laboratory-infected corals & & \\
$\quad$ After 1-3 d (6) & 24 & $3-50$ \\
$\quad$ After 4-7 d (6) & $3 \times 10^{5}$ & $10^{5}-10^{6}$ \\
Bacteria grown in MBTG medium & & \\
1-17 d in seawater (5) & 2 & $1-3$ \\
1-17 d in MBTG (5) & 2 & $1-3$ \\
\hline
\end{tabular}




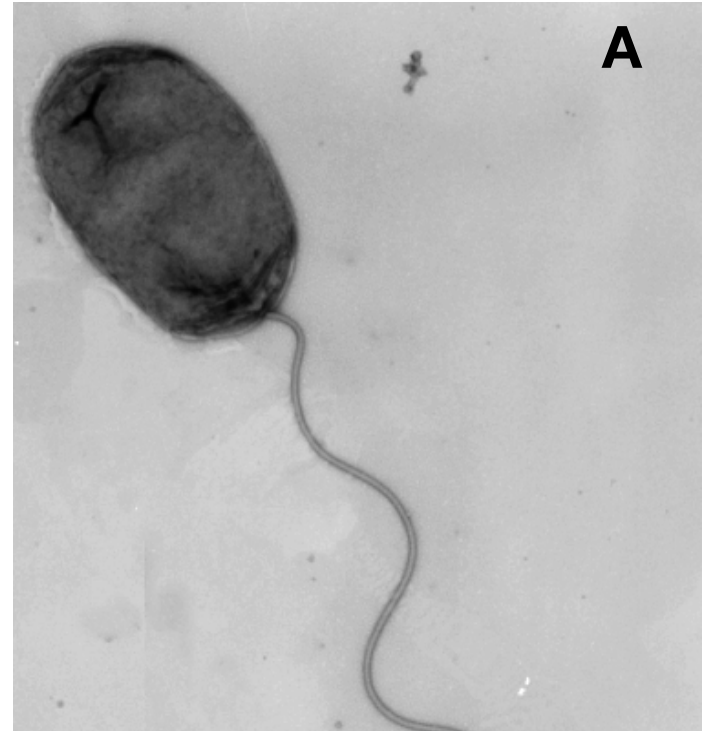

Fig. 3. Electron micrographs of negatively stained Vibrio shiloi. (A) Exponentially growing cells; (B) intracellularly growing cells

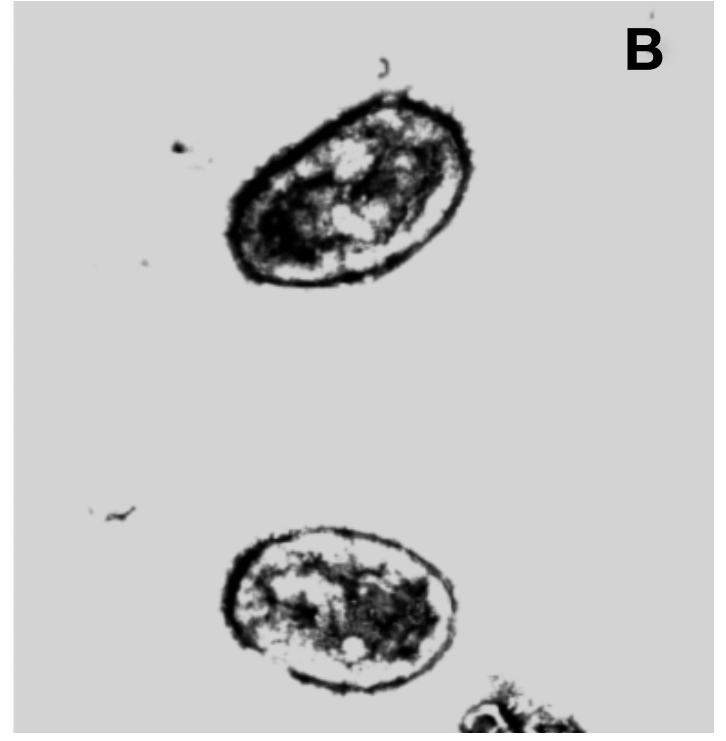

participated in the infection and multiplication, then the average doubling time during the first $48 \mathrm{~h}$ is $3.7 \mathrm{~h}$. Since the previously determined doubling time of V. shiloi in coral tissue was $3.5 \mathrm{~h}$ (Banin et al. 2000), it follows that most of the VBNC bacteria must have penetrated into the tissue and multiplied.

\section{DISCUSSION}

\section{The infectious cycle of Vibrio shiloi}

VBNC state was not infectious, the infection must have been the result of $V$. shiloi in the VBNC state. To reach $4.0 \times 10^{6}$ total cells from an inoculum of 640 would require 13 doublings. Assuming that all VBNC $V$. shiloi

Table 4. Infectivity of the VBNC state of Vibrio shiloi. Four corals, each in $50 \mathrm{ml}$ seawater at $28^{\circ} \mathrm{C}$, were inoculated with a million-fold dilution of a crushed coral that had been infected $96 \mathrm{~h}$ previously with $V$. shiloi. The number of $V$. shiloi was determined by fluorescence microscopy (total counts) and cfu

\begin{tabular}{|lcc|}
\hline Samples examined (n) & \multicolumn{2}{c|}{ Vibrio shiloi } \\
& $\mathrm{cfu}$ & Total count \\
\hline Inoculum & & \\
$\quad 96 \mathrm{~h}$ crushed coral & $2 \times 10^{3}$ & $6.4 \times 10^{8}$ \\
$\quad$ Calculated inoculum per coral & 0.002 & 640 \\
Internal $\boldsymbol{V}$. shiloi after: & & \\
$48 \mathrm{~h}$ & $2.0 \times 10^{3}$ & $4.0 \times 10^{6}$ \\
$144 \mathrm{~h}$ & $1.8 \times 10^{4}$ & $8.5 \times 10^{7}$ \\
Non-inoculated control coral & & \\
$144 \mathrm{~h}$ & - & $<10^{5}$ \\
\hline
\end{tabular}

The data presented here provide additional information on the infectious cycle of Vibrio shiloi in its coral host, Oculina patagonica. Previously, it has been demonstrated that (1) V. shiloi adheres to the coral via a $\beta$-galactoside-containing receptor on the coral surface (Toren et al. 1998), (2) penetrates into the epidermal layer of the coral (Banin et al. 2000), and (3) transforms into a VBNC state and multiplies intracellularly (Banin et al. 2000). During the summer months, when the seawater temperature is high, the bacteria remain at a high cell density, primarily in the VBNC state. In the winter, when the seawater temperature drops, the bacteria are no longer present in the coral tissue. At present, it is not known whether all of the bacteria are killed and lysed, or if some bacteria are released into the seawater. What is clear is that a fresh infection cycle must begin in the spring when the water temperature rises. Since $V$. shiloi can survive for long periods in seawater at $16^{\circ} \mathrm{C}$, outside their host, it is possible that bacteria released by bleached corals provide the inoculum for new infections. Alternatively, fish and 
other marine organisms that feed on corals (Miller \& Hay 1998) could serve as a reservoir for $V$. shiloi during the winter months. In this regard, it is interesting that copepods are a reservoir of Vibrio cholerae (Lobitz et al. 2000). Studies are now being carried out on the mechanism of release of $V$. shiloi from infected corals and the mode of transmission of the coral disease.

\section{The unique VBNC state of intracellular Vibrio shiloi}

A large number of bacterial species have been shown to enter the VBNC state, including several Vibrio species: Vibrio vulnificus (Oliver et al. 1991), Vibrio parahaemolyticus (Chowdhury et al. 1990), Vibrio cholerae (Colwell et al. 1996), and Vibrio fischeri (Lee \& Ruby 1995). All of these VBNC states were induced by stress conditions, such as starvation or low temperature. It has been suggested that the VBNC response may be a genetically programmed differentation which enhances survival during stress (Oliver 1993, McDougald et al. 1998). In the case of $V$. shiloi, the bacteria transform into the VBNC state shortly after they enter the epithelial cells of their coral host, in an environment which is ideal for their growth and multiplication. In fact, $V$. shiloi multiply intracellularly in the VBNC state, clearly demonstrating that they are viable. However, all attempts to obtain colonies on different agar media or growth in liquid media of VBNC V. shiloi have failed. It is possible that a signal present inside the coral is required for multiplication of VBNC $V$. shiloi.

It is particularly interesting that Vibrio shiloi in the VBNC state has the potential to infect healthy corals. Not only did the VBNC $V$. shiloi penetrate into and multiply in the corals (Table 4), but a significant proportion of them transformed back to a culturable form, i.e., cfu. We believe this is convincing evidence for resuscitation. Oliver \& Bockian (1995) demonstrated that non-culturable Vibrio vulnificus was virulent in mice, and Colwell et al. (1996) reported that Vibrio cholerae resuscitated after passing through the digestive system of human volunteers. Also, Legionella pneumophila was transformed from the non-culturable state when passed through the amoeba Acanthamoeba castellanii (Steinert et al. 1997).

\section{Effect of temperature on Vibrio shiloi and a novel coral defense system}

There is a strong correlation between high seawater temperature and coral bleaching (Hoegh-Guldberg 1999). This is clearly the case with bleaching of Oculina patagonica in the Mediterranean Sea (Fig. 1). This correlation has led coral biologists to assume that the high temperature places a stress directly on the coral, causing the loss of the endosymbiotic zooxanthellae. However, the data that have been obtained from studying bleaching of $O$. patagonica by Vibrio shiloi indicate that high temperature exerts its effect on the pathogen rather than on the host. For example, adhesion of $V$. shiloi to $O$. patagonica requires an adhesin on the bacterial surface that recognizes a $\beta$-galactoside receptor on the coral surface. The adhesin is only produced at high temperatures, whereas the coral receptor is produced even at $16^{\circ} \mathrm{C}$ (Toren et al. 1998). In addition, the anti-algal toxins synthesized by the bacterium are produced at much higher levels at summer seawater temperatures than at winter temperatures (Ben-Haim et al. 1999). Furthermore, if not infected, $O$. patagonica remained unbleached and healthy for months at $30^{\circ} \mathrm{C}$ (several control experiments).

In the present study, it was shown that Vibrio shiloi inside coral tissues dies and lyzes when the water temperature is lowered in aquarium experiments or drops naturally in the sea. Since bacteria outside the coral do not die when the temperature is lowered, it follows that the coral must have a mechanism for killing intracellular bacteria. We postulate that one such mechanism is the production of superoxide free radicals $\left(\mathrm{O}_{2}^{-}\right)$from the oxygen generated during photosynthesis. In support of this hypothesis, V. shiloi produces high levels of superoxide dismutase at $30^{\circ} \mathrm{C}$ and very low levels at $16^{\circ} \mathrm{C}$ (Banin et al. unpubl.). Furthermore, mutants of $V$. shiloi lacking superoxide dismutase adhere to corals, penetrate into the coral tissue and then rapidly die - even at $28^{\circ} \mathrm{C}$.

\section{Relevance of the Vibrio shiloi/Oculina patagonica model system to coral bleaching in general}

Although there is no direct data for or against bacteria being the etiological agent of bleaching corals other than Oculina patagonica, the following circumstantial evidence suggests that bacterial bleaching of corals may be widespread. First, the pattern of O. patagonica bleaching closely resembles coral bleaching in other parts of the world: patchiness and spreading nature, loss of pigments and endosymbiotic zooxanthellae and reversibility when the temperature drops. By analogy with well-known animal and plant diseases, identical symptoms often suggest similar pathogens. Second, the frequently observed patchiness and spreading nature of coral bleaching (e.g., Oliver 1985, Lang et al. 1992) is more typical of an infectious agent rather than a stress phenomenon. One would expect adjacent corals in the sea to be exposed to the same conditions.

There are several phenomena discovered in the Vibrio shiloi/Oculina patagonica systsem that may be generally relevant to the study of coral bleaching. First, the 
existence of the VBNC state may make the isolation of pathogens difficult; one way to overcome this problem may be to infect healthy corals with the internal tissues of freshly bleached corals of the same species. Second, since the first step in the infection cycle, adhesion of the bacteria to the coral, is host-specific, one would expect that different bacterial strains would be required to infect different species of corals. Third, a potential coralbleaching pathogen should produce toxins directed at the zooxanthellae. The toxins produced by $V$. shiloi are not host-specific, since they kill zooxanthellae from different coral genera (Ben-Haim et al. 1999). Finally, we would like to stress that if the 'bacterial hypothesis of coral bleaching' is generally correct, then it must be considered in the design and interpretation of experiments and on the development of methods for preventing and curing the coral bleaching disease.

Acknowledgements. This study was supported by the Israel Center for the Study of Emerging Diseases and the Pasha Gol Chair for Applied Microbiology. We thank Elisha Orr for anti$V$. shiloi antibodies and Felix Skandarani for the electron microscopy.

\section{LITERATURE CITED}

Banin E, Israely T, Kushmaro A, Loya Y, Orr E, Rosenberg E (2000) Penetration of the coral-bleaching bacterium Vibrio shiloi into Oculina patagonica. Appl Environ Microbiol 66: 3031-3036

Banin E, Khare SK, Naider F, Rosenberg E (2001) A prolinerich peptide from the coral pathogen Vibrio shiloi that inhibits photosynthesis of zooxanthellae. (Appl Environ Microbiol (in press)

Ben-Haim Y, Banin E, Kushmaro A, Loya Y, Rosenberg E (1999) Inhibition of photosynthesis and bleaching of zooxanthellae by the coral bleaching bacterium Vibrio shiloi. Environ Microbiol 1:223-229

Brown BC (1997) Coral bleaching: causes and consequences. Proc 8th Int Coral Reef Symp 1:65-74

Chowdhury MAR, Yamanaka H, Miyoshi SI, Shinoda S (1990) Ecology and seasonal distribution of Vibrio parahaemolyticus in aquatic environments of a temperate region. FEMS Microbiol Ecol 74:1-10

Colwell RR, Herrington B, Tall A, Huq A, Levine MM (1996) Viable but non-culturable Vibrio cholerae 01 revert to a culturable state in the human intestine. World J Microbiol Biotechnol 12:28-31

Glynn PW (1991a) Coral reef bleaching in the 1980s and possible connections with global warming. Trends Ecol Evol 6:175-179

Glynn PW (1991b) Elimination of two reef building hydrocorals following the 1982-83 El-niño warming event. Science 253:69-71

Hoegh-Guldberg O (1999) Climate change, coral bleaching and the future of the world's coral reefs. Mar Freshw Res 50:839-866

Iglesias-Prieto R, Matta JL, Robins WA, Trench RK (1992) Photosynthetic response to elevated-temperature in the

Editorial responsibility: James Hollibaugh,

Athens, Georgia, USA symbiotic dinoflagellate Symbiodinium microadriaticum in culture. Proc Natl Acad Sci USA 89:302-305

Isberg RR, Falkow S (1985) A single genetic locus encoded by Yersinia pseudotuberculosis permits invasion of cultured animal cells by Escherichia coli K-12. Nature 317:262-264

Jokiel PL, Coles SL (1990) Response of Hawaiian and other Indo Pacific reef corals to elevated temperatures. Coral Reefs 8:155-162

Kushmaro A, Loya Y, Fine M, Rosenberg E (1996) Bacterial infection and coral bleaching. Nature 380:396

Kushmaro A, Rosenberg E, Fine M, Loya L (1997) Bleaching of the coral Oculina patagonica by Vibrio AK-1. Mar Ecol Prog Ser 147:159-165

Kushmaro A, Rosenberg E, Fine M, Ben-Haim Y, Loya Y (1998) Effect of temperature on bleaching of the coral Oculina patagonica by Vibrio shiloi AK-1. Mar Ecol Prog Ser 171: 131-137

Kushmaro A, Banin E, Stackebrandt E, Rosenberg E (2001) Vibrio shiloi sp. nov.: the causative agent of bleaching of the coral Oculina patagonica. Int J Syst Evolut Microbiol (in press)

Lang JC, Lasker HR, Gladfelter EH, Hallock P, Jaap WC, Losada FJ, Muller RG (1992) Spatial and temporal variability during periods of 'recovery' after mass bleaching on Western Atlantic coral reefs. Am Zool 32:696-706

Lee KI, Ruby EG (1995) Symbiotic role of the viable but nonculturable state of Vibrio fischeri in Hawaiian coastal seawater. Appl Environ Microbiol 61:278-283

Lobitz B, Beck L, Huq A, Wood B, Fuchs G, Faruque ASG, Colwell R (2000) Climate and infectious disease: use of remote sensing for detection of Vibrio cholerae by indirect measurement. Proc Natl Acad Sci USA 97:1438-1443

McDougald D, Rice SA, Weichart D, Kjelleberg S (1998) Nonculturability: adaptation or debilitation? FEMS Microbiol Ecol 25:1-9

Miller MW, Hay ME (1998) Effects of fish predation and seaweed competition on the survival and growth of corals. Oecologia 113:231-238

Oliver J (1985) Recurrent seasonal bleaching and mortality of corals on the Great Barrier Reef. Proc 5th Int Coral Reef Symp Tahiti 4:201-206

Oliver JD (1993) Formation of viable but nonculturable cells. In: Kjelleberg S (ed) Starvation in bacteria. Plenum Press, New York, p 239-272

Oliver JD, Bockian R (1995) In vivo resuscitation, and virulence towards mice, of viable but nonculturable cells of Vibrio vulnificus. J Bacteriol 61:2620-2623

Oliver JD, Nilsson L, Kjelleberg S (1991) Formation of nonculturable Vibrio vulnificus cells and its relationship to the starvation state. Appl Environ Microbiol 57:2640-2644

Rosenberg E, Ben-Haim Y, Toren A, Banin E, Kushmaro A, Fine M, Loya Y (1998) Effect of temperature on bacterial bleaching of corals. In: Rosenberg E (ed) Microbial ecology and infectious disease. ASM Press, Washington, DC, p 242-254

Steinert M, Emody L, Amann R, Hacker J (1997) Resuscitation of viable but nonculturable Legionella pneumophila Philadelphia JR32 by Acanthamoeba castellanii. Appl Environ Microbiol 63:2047-2053

Toren A, Landau L, Kushmaro A, Loya Y, Rosenberg E (1998) Effect of temperature on adhesion of Vibrio strain AK-1 to Oculina patagonica and on coral bleaching. Appl Environ Microbiol 64:1379-1384

Wilkinson C (1998) Status of coral reefs of the world. Australian Institute of Marine Science Publication, Townsville

Submitted: October 1, 2000; Accepted: February 20, 2001

Proofs received from author(s): February 28, 2001 